\title{
THE COMPLEMENTARY EFFECT OF BIOSTIMULANTS AND NITROGEN FERTILIZER ON IMPROVING THE GROWTH AND PRODUCTIVITY OF SQUASH (CUCURBITA PEPO L.)
}

\author{
M.A. Taha \\ Horticulture Dept., Fac. of Agric., Menoufia Univ., Shebin El- Kom, Egypt. \\ Corresponding author email; mohamed.taha@agr.menofia.edu.eg
}

Received: Nov. 7, 2021

Accepted: Nov. 28, 2021

\begin{abstract}
Field research experiments were conducted during the two successive growing seasons of 2019/2020 and 2020 in the Experimental Farm, Faculty of Agriculture, Menoufia University to evaluate changes in growth, nutritional contents and yield of squash (Cucurbita pepo L.) under the foliar application of four biostimulant treatments i.e., aqueous moringa leaf extract at 1:30 v/v (MLE) and potent microorganisms at $20 \mathrm{~mL}$ $\mathrm{L}^{-1}$ (EM1) as natural growth regulators each alone or tougher or in combinations with $\mathrm{N}$ at rates of 0,75 and $100 \%$ of the recommended nitrogen fertilization rate. This research was coordinated in a Split plot design in three replications. The results showed that the addition of nitrogen at $100 \%$ led to a maximum significant increase in the growth chrematistics, that is, the number of leaves and the fresh and dry weight of leaves compared to the unfertilized control. The chlorophyll contents increase significantly with increasing $\mathbf{N}$ supply up to $75 \%$ with moringa leaf extract foliar application. The highest $\mathbf{N}$, $P$ and $K$ contents were found in squash leaves treated with $N$ at $100 \%$ of the recommended rate. The yield and its components of squash plants increased significantly with the increased of nitrogen supply up to $100 \%$ of the recommended rate. Combined application of EM1 and MLE resulted in a significant increase in growth traits and fruit yield compared to the control treatment.
\end{abstract}

Key words: $\mathrm{N}$ rates - EM1 - Moringa oleifera Leaf Extract - squash - quality

\section{INTRODUCTION}

Squash is a member of the Cucurbitaceae family and is one of the most frequently grown fruit vegetables around the world. Squash is classified as a high-level vegetable input, due to its high ability to produce a lot of biomass crop and its nutritional requirements in any case (Colla and Saccardo 2003). It is known that excessive nitrogen fertilization may increase plant activity and prolong the plant cycle, causing delayed harvest, nitrate accumulation in plant tissues and environmental pollution (Kant et al. 2011). Unfortunately, chemical fertilizers cause soil degradation and pollute the environment, despite their high costs. Recently, in modern agriculture and horticulture finding alternative and innate sources of biostimulants has been the main objective of interest for achieving future cultivation and improving crop yields (Abdalla 2013 and Calvo et al. 2014). Any prosperity in the farming system that leads to higher production must reduce the negative environmental impact of agriculture and enhance the sustainability of the system.

Application of plant extracts as stimulators/growth regulator (PGRs) is one of the approaches recently adopted in agricultural, particularly within a poor agricultural country striving to become more economically and socially advanced. During this endeavour, plant extracts enriched with bioactive compounds are used as growth stimulants due to the presence of allyl chemicals within the plant leaves such as 
Zeatin in moringa leaves, it has the potential along with other inorganic salts to promote growth expansion and the yield, similarly can alter the range of physiological and biochemical processes in plant cell metabolism (Yaronskaya et al. 2006, Tilly-Mándy et al. 2010 and Ashraf et al. 2016). One of all exogenous plant biostimulants is Effective Microorganisms (EM) which is a mixture of beneficial and effective microorganism which will be set by two methods of soil irrigation or foliar spraying. EM contains preferred types of microorganisms, including dominant groups of lactic acid bacteria, yeasts, smaller numbers of photosynthetic bacteria, actinomycetes and other types of organisms.

All of these are supposed to be mutually compatible with each other and are able to coexist in culture. EM plays a beneficial role in improving flower starter formation due to its effect on carbohydrates accumulation. It also has a stimulating effect on the biological process and amplification, protein and DNA synthesis and chlorophyll formation (Swelam, 2012 and Hamail et al. 2014). The importance of plant biostimulants consist of several bioactive compounds that may enhance various physiological processes, thus stimulating plant growth as well as productivity. on the other hand, reduce chemical fertilizers and increase nutrient utilization efficiency (Bulgari et al. 2015). Moringa leaf extract (MLE) is one of the ultimate plant biostimulants and can be used as a natural and alternative source of mineral nutrition (Phiri and Mbewe 2010). Recently, MLE has received a lot of attained regarding its beneficial applications and it contains cytokinins such as zeatin, antioxidants such as ascorbic acid, amino acids, flavonoid, carotenoids, vitamins $A$ and $C$, phenolics, macronutrients as well as micronutrients (Rady et al. 2013, Latif and Mohamed 2016 and Gopalakrishnan et al. 2016).
Interestingly, not only the stimulant content of MLE, but also the balance between the contents of phytohormones, nutrients and antioxidants make it an excellent natural prebiotic of plants (Azra et al. 2013). The main hormone observed in MLE is zeatin and its intensity is almost thousands of times higher than that of the most studied plants to date (Rady et al. 2013). MLE has been used as a natural and eco-friendly biostimulant to improve growth and productivity traits of many crops grown under natural conditions (Rehman et al. 2015, Ashraf et al. 2016, El zaawely et al. 2016 and Nasir et al. 2016) and even under stresses as well (Azra et al. 2013, Howladar 2014 and Latif and Mohamed 2016) and thus results in higher economic return. In addition, Ndubuaku et al. (2015) reported that plant height and number of leaves in cassava plants were increased mandatory for foliar application of MLE. In a comparative study by Aslam et al. (2016) observed that MLE application significantly increased the total chlorophyll content and soluble protein content in spinach leaves compared to growth regulators studied.

\section{MATERIALS AND METHODS}

\section{Field Experiment}

Mielit hybrid squash seeds were used in this study. The seeds were sown on August 24 and 29 in 2019 and 2020 seasons, respectively in an open field on clay loam soil under surface irrigation system. The seeds were sown in rows with a distance of $40 \mathrm{~cm}$ between each hill and other. The rows were 4 meters in length and $70 \mathrm{~cm}$ in width. Each experimental plot area consists of four rows with a total area of $11.2 \mathrm{~m}^{2}$. The physical and chemical analysis was performed by the Soil Testing Laboratory of the College of Agriculture according to standard procedures (Wilde et al., 1985) and the data obtained were presented in Table 1. 
Table (1) The main characteristics of the physical and chemical analysis of soil

\begin{tabular}{|c|c|c|c|c|c|c|c|c|c|c|c|c|c|}
\hline \multicolumn{6}{|c|}{ Physical properties } & & \multicolumn{6}{|c|}{ Chemical properties } & \multirow{3}{*}{\begin{tabular}{|c|}
$\begin{array}{c}\text { Bulk } \\
\text { density }\end{array}$ \\
$\mathbf{g} / \mathbf{c m}^{3}$ \\
\end{tabular}} \\
\hline \multicolumn{3}{|c|}{$\begin{array}{l}\text { Practical size } \\
\text { distribution }\end{array}$} & \multirow[t]{2}{*}{ Texture } & \multirow[t]{2}{*}{ pH } & \multirow[t]{2}{*}{$\begin{array}{c}\mathrm{EC} \\
\text { m.mhos }\end{array}$} & \multirow[t]{2}{*}{$\begin{array}{l}\text { Organic } \\
\text { matter\% }\end{array}$} & \multicolumn{3}{|c|}{ Cation meq/l } & \multicolumn{3}{|c|}{ Anion meq/l } & \\
\hline Sand\% & Silt \% & Clay\% & & & & & $\mathrm{Ca}^{++}$ & $\mathrm{Mg}^{++}$ & $\mathrm{Na}^{++}$ & $\mathrm{Cl}^{-}$ & $\mathrm{HCO}_{3}{ }^{-}$ & $\mathrm{SO}_{4}^{-}$ & \\
\hline 31.89 & 23.93 & 41.29 & $\begin{array}{l}\text { Clay } \\
\text { loam }\end{array}$ & 7.5 & 0.42 & 1.73 & 0.75 & 0.56 & 0.30 & 4.35 & 0.60 & 02.00 & 1.55 \\
\hline
\end{tabular}

\section{Treatments and Experimental Design}

This trial consisted of 12 treatments which were all related to three nitrogen fertilizer rates i.e., 0,75 and $100 \%$ and four biostimulants i.e., 0, EM1, MLE and EM1+MLE and their combination. The treatments were coordinated in a split plot design, with three replicates. Fertilizer $\mathbf{N}$ rates were set as the main plot while, biostimulants treatments were set as a sub plot factor.

\section{NPK Fertilizer Application}

A constant dose of calcium super phosphate $\left(15.5 \% \mathrm{P}_{2} \mathrm{O}_{5}\right)$ was received for all experimental plots at $200 \mathrm{~kg}$ fed. ${ }^{-1}$ during land planning. Potassium fertilizer in the form of potassium sulphate $(48 \%$ $\mathrm{K}_{2} \mathrm{O}$ ) at $100 \mathrm{~kg}^{\mathrm{fed}}{ }^{-1}$ was tied up in two equal doses, 3 and 6 weeks after sowing. Nitrogen fertilizer doses were used as 0 , 75 and $100 \%$ of the recommended fertilizer rate. Nitrogen fertilizer was applied based on nitrogen equivalent i.e., $120 \mathrm{~kg} \mathrm{fed}^{-1}$ as the recommended medium using mineral fertilizer from ammonium sulphate fertilizer $(20.5 \% \mathrm{~N})$. The amount of nitrogen fertilizer was divided into four equal parts during soil preparation and the remainder was added to each plot three weeks from sowing and repeated with 2 weeks intervals. Recommended agricultural management practices have been implemented for commercial production of squash (under the supervision of Egyptian Ministry of Agriculture).

\section{Bio-Stimulants Application}

Foliar applications including four biostimulants treatments i.e., foliar application of water, EM1, MLE, and EM1
+MLE. EM1 (Effective microorganisms) at $20 \mathrm{ml} \mathrm{L}^{-1}$. Moringa Leaf Extract (MLE) were prepared by harvesting fresh leaves and extracting them at full maturity stage. For extraction, the aqueous extract of moringa was prepared at a ratio of 1:30 (w/vol) by methods of (Phiri and Mbewe 2010), and the extracts were frozen overnight and pressed in a locally fabricated machine and purified twice by filtering through filter paper (Whatman No.1). After the refining process, the extract was centrifuged at $8000 \times g$ for15 min to the diluted supernatant to obtain the extraction at a concentration of $3 \%$ for spraying the plant leaves (Azra et al., 2013) and its mixture plus control treatment (pure water). The spraying treatments started three weeks after the planting date and were repeated 3 times with an interval of 15 days during the growing seasons.

\section{Evaluated Parameters \\ Plant sampling}

In each experimental plot, three plants from the outer two rows were randomly selected for morphological characters and chemical composition, while the middle two rows were selected to determine the yield of fruits and its components.

\section{Vegetative Characteristics Measured}

Squash growth parameters data were obtained 1 week after the last foliar application of biostimulants i.e., 65 days for measurements. Number of leaves and fresh weight of leaves as well as its dry weight which were oven dried at $70^{\circ} \mathrm{C}$ until the weight stabilized were recorded. 


\section{Chlorophyll and Chemical Constitutes}

Chlorophyll reading was determined in the fourth of the fully functional mature upper leaves, 1 week after the last foliar application of the biostimulant, using a portable chlorophyll meter (SPAD-502, Minolta Corporation, Ltd., Osaka, Japan). Twenty-one leaves were randomly measured per plot and averaged to a single SPAD value per treatment. Dry leaf samples were digested with concentrated sulfuric acid and $\mathrm{H}_{2} \mathrm{O}_{2}$ and analysed for N-P-K nutrients as described by Cottenie et al. (1982).

\section{Yield and its components}

There were eight picking that started at 44 days after planting and seven picking were carried out. Edible fruits were harvested from each sub-plot for eight times and the number of fruits/plants and total yield/plot were recorded by summarizing the successive harvest periods.

\section{Fruit quality}

It was determined in the middle of the harvest season using some fruits at random from each plot, as follows:

1- The physical characteristics of fruits, such as diameter of the fruit, a sample of five fruits in an edible stage was taken randomly from each sub plot in the second picking to determine the diameter,

2- The dry matter percentage of the fruits was determined as $100 \mathrm{~g}$ of each sub plot taken and dried at $70{ }^{\circ} \mathrm{C}$ to a constant weight and the average of dry weight was determined using standard methods as described in (AOAC, 1990),

3- The percentage of total soluble solids (TSS \%) in edible fruit juice was estimated using a hand refractometer.

\section{Statistical Analysis}

All data obtained were statistically analysed by ANOVA using the COSTAT (2020) package. Duncan's multiple range test was performed at $P=0.05$ on each of the significant variables that were measured.

\section{RESULTS AND DISCUSSION}

\section{Plant Growth}

The results presented in Tables $(2,3$ and 4) show the effect of the nitrogen fertilization levels and the implementation of biostimulants either alone or in their combinations effect on the vegetative growth characteristics of squash plants, expressed as the number of leaves and fresh and dry weight of leaves. In terms of fertilizer rates, different effects were observed as there was a prevailing trend on increasing growth traits with increasing fertilizer up to the highest level of $100 \% \mathrm{~N}$. Plants that obtained $75 \% \mathrm{~N}$ combined with the biostimulants significantly increased growth characteristics with a clear superiority to $100 \% \mathrm{~N}$ relative to unfertilized observation. However, the dry weight of leaves for plants that obtained $100 \%$ nitrogen was almost twice that of unfertilized plants. The increase in vegetative characteristics with an increase in the fertilizer rate may be attributed to higher nitrogen supply and an increase in nitrogen uptake and its associated role in chlorophyll synthesis and thus photosynthesis and carbon dioxide assimilation (Jasso-Chaverria et al. 2005). Nitrogen has been described as dominating plant growth by being a major component of chlorophyll, protein and amino acids which plays an important role in photosynthesis activity (Sumeet et al. 2009). In the same way, based on the high leaf biomass, the results can be attributed to the aforementioned increase in leaf number and can be attributed to the role of 
nitrogen in the formation of dry and fresh matter as well as various energy-rich compounds that regulates photosynthesis and plant production (Wu et al. 1998). Our findings coincide with (Pokluda et al., 2018) those of previous squash studies which reported that plants treated with $0,75,100$ and $150 \mathrm{~kg}$ $\mathrm{N}$ ha $^{-1}$ were different from the control group $(0 \mathrm{~N})$ about $21.0 \%$ on influencing on leaf number and biomass yield of 100 and $150 \mathrm{~kg} \mathrm{~N} \mathrm{ha}^{-1}$ was about $99 \%$ higher than that of the control.

Table (2): Effect of biostimulants, nitrogen rates and their interactions on the number of leaves/plants

\begin{tabular}{|c|c|c|c|c|c|c|c|c|}
\hline \multirow{2}{*}{ Treatments } & \multicolumn{7}{c|}{ Seasons } \\
& \multicolumn{7}{|c|}{$2019 / 2020$} & N levels \\
& $0 \%$ & $75 \%$ & $100 \%$ & Mean & $0 \%$ & $75 \%$ & $100 \%$ & Mean \\
\hline Control & $18.00^{\mathrm{a}}$ & $20.33^{\mathrm{a}}$ & $21.33^{\mathrm{a}}$ & $19.89^{\mathrm{B}}$ & $18.33^{\mathrm{a}}$ & $20.67^{\mathrm{a}}$ & $25.00^{\mathrm{a}}$ & $21.33^{\mathrm{B}}$ \\
\hline EM1 & $20.00^{\mathrm{a}}$ & $21.00^{\mathrm{a}}$ & $25.33^{\mathrm{a}}$ & $22.11^{\mathrm{AB}}$ & $20.67^{\mathrm{a}}$ & $21.33^{\mathrm{a}}$ & $25.63^{\mathrm{a}}$ & $22.54^{\mathrm{AB}}$ \\
\hline MLE & $21.00^{\mathrm{a}}$ & $23.00^{\mathrm{a}}$ & $25.67^{\mathrm{a}}$ & $23.22^{\mathrm{AB}}$ & $22.00^{\mathrm{a}}$ & $25.00^{\mathrm{a}}$ & $26.43^{\mathrm{a}}$ & $24.48^{\mathrm{AB}}$ \\
\hline EM1 + MLE & $21.33^{\mathrm{a}}$ & $24.28^{\mathrm{a}}$ & $27.67^{\mathrm{a}}$ & $24.43^{\mathrm{A}}$ & $23.33^{\mathrm{a}}$ & $25.67^{\mathrm{a}}$ & $28.09^{\mathrm{a}}$ & $25.70^{\mathrm{A}}$ \\
\hline Mean & $20.08^{\mathrm{B}}$ & $22.15^{\mathrm{A}}$ & $25.00^{\mathrm{A}}$ & & $21.08^{\mathrm{B}}$ & $23.17^{\mathrm{A}}$ & $26.29^{\mathrm{A}}$ & \\
\hline
\end{tabular}

Table (3): Effect of biostimulants, nitrogen rates and their interactions on the fresh weight of leaves ( $\mathrm{g} / \mathrm{plant})$

\begin{tabular}{|c|c|c|c|c|c|c|c|c|}
\hline \multirow{2}{*}{ Treatments } & \multicolumn{7}{|c|}{$2019 / 2020$} & Neasons \\
& \multicolumn{7}{|c|}{ levels } & \multicolumn{7}{c|}{$2020 / 2021$} \\
\hline & $0 \%$ & $75 \%$ & $100 \%$ & Mean & $0 \%$ & $75 \%$ & $100 \%$ & Mean \\
\hline Control & $638.85^{\mathrm{a}}$ & $864.95^{\mathrm{a}}$ & $1233.24^{\mathrm{a}}$ & $912.35^{\mathrm{C}}$ & $715.42^{\mathrm{a}}$ & $947.35^{\mathrm{a}}$ & $1352.57^{\mathrm{a}}$ & $1005.11^{\mathrm{C}}$ \\
\hline EM1 & $1152.36^{\mathrm{a}}$ & $1218.64^{\mathrm{a}}$ & $1467.85^{\mathrm{a}}$ & $1279.62^{\mathrm{B}}$ & $1294.37^{\mathrm{a}}$ & $1342.58^{\mathrm{a}}$ & $1549.34^{\mathrm{a}}$ & $1395.43^{\mathrm{B}}$ \\
\hline MLE & $1234.58^{\mathrm{a}}$ & $1438.84^{\mathrm{a}}$ & $1589.37^{\mathrm{a}}$ & $1420.93^{\mathrm{B}}$ & $1329.48^{\mathrm{a}}$ & $1536.26^{\mathrm{a}}$ & $1684.07^{\mathrm{a}}$ & $1516.60^{\mathrm{B}}$ \\
\hline EM1 + MLE & $1476.54^{\mathrm{a}}$ & $1688.28^{\mathrm{a}}$ & $1843.33^{\mathrm{a}}$ & $1669.38^{\mathrm{A}}$ & $1514.21^{\mathrm{a}}$ & $1709.34^{\mathrm{a}}$ & $1987.94^{\mathrm{a}}$ & $1737.16^{\mathrm{A}}$ \\
\hline Mean & $1125.58^{\mathrm{B}}$ & $1302.68^{\mathrm{AB}}$ & $1533.45^{\mathrm{A}}$ & & $1213.37^{\mathrm{B}}$ & $1383.88^{\mathrm{AB}}$ & $1643.48^{\mathrm{AB}}$ & \\
\hline
\end{tabular}

Table (4): Effect of biostimulants, nitrogen rates and their interactions on the dry weight of leaves (g/plant)

\begin{tabular}{|c|c|c|c|c|c|c|c|c|}
\hline Treatments & \multicolumn{7}{|c|}{$2019 / 2020$} & Neasons \\
& \multicolumn{7}{|c|}{ N levels } \\
\hline & $0 \%$ & $75 \%$ & $100 \%$ & Mean & $0 \%$ & $75 \%$ & $100 \%$ & Mean \\
\hline Control & $46.33^{\mathrm{a}}$ & $70.27^{\mathrm{a}}$ & $94.42^{\mathrm{a}}$ & $70.34^{\mathrm{B}}$ & $49.56^{\mathrm{a}}$ & $73.48^{\mathrm{a}}$ & $102.33^{\mathrm{a}}$ & $75.12^{\mathrm{C}}$ \\
\hline EM1 & $68.88^{\mathrm{a}}$ & $94.88^{\mathrm{a}}$ & $114.47^{\mathrm{a}}$ & $92.74^{\mathrm{A}}$ & $70.24^{\mathrm{a}}$ & $96.85^{\mathrm{a}}$ & $123.48^{\mathrm{a}}$ & $96.86^{\mathrm{B}}$ \\
\hline MLE & $66.62^{\mathrm{a}}$ & $90.45^{\mathrm{a}}$ & $121.34^{\mathrm{a}}$ & $92.80^{\mathrm{AB}}$ & $69.52^{\mathrm{a}}$ & $94.48^{\mathrm{a}}$ & $130.45^{\mathrm{a}}$ & $98.15^{\mathrm{AB}}$ \\
\hline EM1 + MLE & $90.14^{\mathrm{a}}$ & $116.33^{\mathrm{a}}$ & $128.36^{\mathrm{a}}$ & $111.61^{\mathrm{A}}$ & $92.35^{\mathrm{a}}$ & $119.48^{\mathrm{a}}$ & $139.40^{\mathrm{a}}$ & $117.08^{\mathrm{A}}$ \\
\hline Mean & $67.99^{\mathrm{C}}$ & $92.98^{\mathrm{BC}}$ & $114.56^{\mathrm{A}}$ & & $70.42^{\mathrm{C}}$ & $96.07^{\mathrm{AB}}$ & $123.92^{\mathrm{A}}$ & \\
\hline
\end{tabular}


As for the biostimulants, different effects were observed, the number of leaves and the fresh and dry weight of squash leaves were effectively improved by the application of the biostimulants either individually or in a combination manner relative to untreated treatment. These effects were significant and maximal with MLE application when combined with EM1. EM1contains selected types of microorganisms, including dominant groups of lactic acid bacteria, yeasts, a smaller number of photosynthetic bacteria, actinomycetes and various types of organisms. It is claimed that all these elements are mutually compatible with each other and able to coexist in culture. Also, it has a stimulatory effect on cell division and hypertrophy, protein and DNA synthesis and chlorophyll formation (Hamail et al., 2014).

In addition, moringa leaf extract is high in phytohormones, especially zeatin, gibberellins and ABA (Rady et al., 2013 and Rady and Mohamed, 2015). Moringa leaf extract is also rich in different classes of plant hormones, especially salicylates, including benzoic, cinnamic and salicylic acids. Moreover, moringa leaves are rich in essential amino acids, minerals and vitamins (A, B1, B2, B3, C, and $E$ ) as well as antioxidant compounds such as phenolics (Basra et al., 2011, Busani et al., 2011, Howladar, 2014 and EI Sohaimy et al., 2015). The effect of size with combinations of Moringa leaf extract + Effective Microorganisms from the single agent may be attributed to the complementarity of each other and this integration could be suggested to increase the effect of the integrated application on growth characteristics. Therefore, these results can also be also attributed to the catalytic effect on photosynthetic pigments and mineral contents (Tables 5, 6, 7 and 8).

\section{Chlorophyll Contents}

The results presented in Table (5) show the effect of the levels of $N$ fertilization and the implementation of biostimulants either alone or through combinations as well as the effect of the interactions on chlorophyll contents. Compared with the competent control, the chlorophyll reading increased significantly as the nitrogen supply increased by $100 \%$. A large interaction of chlorophyll content that leads to more efficient use when both are at a satisfactory level (75 and $100 \% \mathrm{~N}$ of the recommended rate) may be an indication that the nitrogen has been taken up by the plant and then used in cell multiplication, DNA synthesis and energy formation that acts as structural for photosynthesis chloroplast. It has been confirmed that nitrogen is one of the components of chlorophyll formation as described in (Lawlor, 2002). In contrast, it was observed that nitrogen deficiency concentration reduced the individual leaf area index and the total leaf area decreased light interception for photosynthesis (Cechin and Fumis, 2004).

Regarding the effect of biostimulants, in general, the results show that spraying squash plants with EM1 or MLE either alone or in combinations increase the chlorophyll content compared to the control. The most effective and significant values were recorded by EM1+ MLE foliar spray. The modified chlorophyll content and photosynthetic vigour of spinach and radish leaves were observed by Aslam et al. (2016) and Ashraf et al. (2016), respectively. The effect of the interactions between nitrogen fertilizers and the biostimulants on chlorophyll contents were consistent, indicating that both factors do not act individually. The superior combinations of treatments were $100 \% \mathrm{~N}$ of the recommended rate associated with the EM1 + MLE mixture compared with all possible combinations tested. 
Table (5): Effect of biostimulants, nitrogen rates and their interactions on the chlorophyll content

\begin{tabular}{|c|c|c|c|c|c|c|c|c|}
\hline Treatments & \multicolumn{7}{|c|}{$2019 / 2020$} & Seasons \\
& \multicolumn{7}{|c|}{ N levels } \\
& $0 \%$ & $75 \%$ & $100 \%$ & Mean & $0 \%$ & $75 \%$ & $100 \%$ & Mean \\
\hline Control & $39.00^{\mathrm{d}}$ & $41.40^{\mathrm{d}}$ & $41.84^{\mathrm{d}}$ & $40.75^{\mathrm{C}}$ & $41.20^{\mathrm{C}}$ & $41.48^{\mathrm{d}}$ & $45.90^{\mathrm{d}}$ & $42.86^{\mathrm{C}}$ \\
\hline EM1 & $41.14^{\mathrm{C}}$ & $43.40^{\mathrm{C}}$ & $47.36^{\mathrm{C}}$ & $43.97^{\mathrm{B}}$ & $42.00^{\mathrm{C}}$ & $45.04^{\mathrm{C}}$ & $48.90^{\mathrm{C}}$ & $45.31^{\mathrm{B}}$ \\
\hline MLE & $41.60^{\mathrm{b}}$ & $46.52^{\mathrm{b}}$ & $49.46^{\mathrm{b}}$ & $45.86^{\mathrm{AB}}$ & $44.06^{\mathrm{b}}$ & $49.00^{\mathrm{b}}$ & $51.80^{\mathrm{bC}}$ & $48.29^{\mathrm{AB}}$ \\
\hline EM1 + MLE & $44.10^{\mathrm{a}}$ & $47.40^{\mathrm{a}}$ & $51.00^{\mathrm{a}}$ & $47.50^{\mathrm{A}}$ & $45.20^{\mathrm{a}}$ & $50.80^{\mathrm{a}}$ & $54.00^{\mathrm{a}}$ & $50.00^{\mathrm{A}}$ \\
\hline Mean & $41.46^{\mathrm{C}}$ & $44.68^{\mathrm{B}}$ & $47.42^{\mathrm{A}}$ & & $43.11^{\mathrm{C}}$ & $46.58^{\mathrm{B}}$ & $50.15^{\mathrm{A}}$ & \\
\hline
\end{tabular}

Table (6) Effect of biostimulants, nitrogen rates and their interactions on the nitrogen \%

\begin{tabular}{|c|c|c|c|c|c|c|c|c|}
\hline Treatments & \multicolumn{7}{|c|}{$2019 / 2020$} & Seasons \\
& \multicolumn{7}{|c|}{ N levels } \\
\hline & $0 \%$ & $75 \%$ & $100 \%$ & Mean & $0 \%$ & $75 \%$ & $100 \%$ & Mean \\
\hline Control & $2.22^{\mathrm{f}}$ & $2.61^{\mathrm{C}-\mathrm{e}}$ & $3.21^{\mathrm{e}}$ & $2.68^{\mathrm{C}}$ & $2.28^{\mathrm{e}}$ & $2.73^{\mathrm{C}-\mathrm{d}}$ & $3.36^{\mathrm{d}}$ & $2.79^{\mathrm{C}}$ \\
\hline EM1 & $2.68^{\mathrm{e}}$ & $2.86^{\mathrm{ef}}$ & $3.42^{\mathrm{a}-\mathrm{d}}$ & $2.99^{\mathrm{B}}$ & $2.89^{\text {ef }}$ & $2.94^{\mathrm{d}}$ & $3.52^{\mathrm{C}}$ & $3.12^{\mathrm{B}}$ \\
\hline MLE & $2.74^{\mathrm{e}-\mathrm{f}}$ & $2.91^{\mathrm{de}}$ & $3.53^{\mathrm{b}}$ & $3.06^{\mathrm{A}}$ & $2.81^{\mathrm{ab}}$ & $2.98^{\mathrm{b}}$ & $3.64^{\mathrm{b}}$ & $3.14^{\mathrm{AB}}$ \\
\hline EM1 + MLE & $3.31^{\mathrm{a}-\mathrm{d}}$ & $3.45^{\mathrm{C}-\mathrm{e}}$ & $4.11^{\mathrm{a}}$ & $3.62^{\mathrm{A}}$ & $3.37^{\mathrm{a}}$ & $3.56^{\mathrm{a}}$ & $4.13^{\mathrm{a}}$ & $3.69^{\mathrm{A}}$ \\
\hline Mean & $2.74^{\mathrm{C}}$ & $2.96^{\mathrm{B}}$ & $3.57^{\mathrm{A}}$ & & $2.84^{\mathrm{C}}$ & $3.05^{\mathrm{B}}$ & $3.66^{\mathrm{A}}$ & \\
\hline
\end{tabular}

Table(7): Effect of biostimulants, nitrogen rates and their interactions on the phosphors $\%$

\begin{tabular}{|c|c|c|c|c|c|c|c|c|}
\hline \multirow[t]{3}{*}{ Treatments } & \multicolumn{8}{|c|}{ Seasons } \\
\hline & \multirow{2}{*}{\multicolumn{4}{|c|}{$2019 / 2020$}} & \multicolumn{4}{|c|}{$2020 / 2021$} \\
\hline & & & & & \multicolumn{4}{|c|}{$\mathbf{N}$ levels } \\
\hline & $0 \%$ & $75 \%$ & $100 \%$ & Mean & $0 \%$ & $75 \%$ & $100 \%$ & Mean \\
\hline Control & $0.39^{d}$ & $0.43^{\mathrm{d}}$ & $0.46^{\mathrm{c}}$ & $0.43^{C}$ & $0.40^{\mathrm{d}}$ & $0.44^{\mathrm{d}}$ & $0.47^{c}$ & $0.44^{C}$ \\
\hline EM1 & $0.46^{c}$ & $0.51^{c}$ & $0.56^{\mathrm{b}}$ & $0.51^{\mathrm{B}}$ & $0.47^{c}$ & $0.52^{c}$ & $0.58^{\mathrm{b}}$ & $0.52^{\mathrm{B}}$ \\
\hline MLE & $0.49^{\text {ab }}$ & $0.56^{6}$ & $0.61^{\mathrm{ab}}$ & $0.55^{\mathrm{B}}$ & $0.49^{b}$ & $0.58^{6}$ & $0.63^{b}$ & $0.57^{B}$ \\
\hline EM1 + MLE & $0.50^{\mathrm{a}}$ & $0.63^{\mathrm{a}}$ & $0.70^{a}$ & $0.61^{A}$ & $0.50^{\mathrm{a}}$ & $0.64^{\mathrm{a}}$ & $0.70^{\mathrm{a}}$ & $0.61^{A}$ \\
\hline Mean & $0.46^{B}$ & $0.53^{A}$ & $0.58^{A}$ & & $0.47^{B}$ & $0.55^{A}$ & $0.60^{A}$ & \\
\hline
\end{tabular}

Table (8): Effect of biostimulants, nitrogen rates and their interactions on the potassium\%

\begin{tabular}{|c|c|c|c|c|c|c|c|c|}
\hline Treatments & \multicolumn{7}{|c|}{$2019 / 2020$} & Seasons \\
& \multicolumn{7}{|c|}{ N levels } \\
& $0 \%$ & $75 \%$ & $100 \%$ & Mean & $0 \%$ & $75 \%$ & $100 \%$ & Mean \\
\hline Control & $3.30^{\mathrm{a}}$ & $3.51^{\mathrm{a}}$ & $4.06^{\mathrm{a}}$ & $3.62^{\mathrm{A}}$ & $3.41^{\mathrm{a}}$ & $3.52^{\mathrm{a}}$ & $4.10^{\mathrm{a}}$ & $3.68^{\mathrm{A}}$ \\
\hline EM1 & $3.76^{\mathrm{a}}$ & $3.79^{\mathrm{a}}$ & $4.15^{\mathrm{a}}$ & $3.90^{\mathrm{A}}$ & $3.77^{\mathrm{a}}$ & $3.81^{\mathrm{a}}$ & $4.16^{\mathrm{a}}$ & $3.91^{\mathrm{A}}$ \\
\hline MLE & $3.77^{\mathrm{a}}$ & $3.81^{\mathrm{a}}$ & $4.25^{\mathrm{a}}$ & $3.94^{\mathrm{A}}$ & $3.78^{\mathrm{a}}$ & $3.83^{\mathrm{a}}$ & $4.29^{\mathrm{a}}$ & $3.97^{\mathrm{A}}$ \\
\hline EM1 + MLE & $3.79^{\mathrm{a}}$ & $3.82^{\mathrm{a}}$ & $4.32^{\mathrm{a}}$ & $3.98^{\mathrm{A}}$ & $3.80^{\mathrm{a}}$ & $3.84^{\mathrm{a}}$ & $4.38^{\mathrm{a}}$ & $4.01^{\mathrm{A}}$ \\
\hline Mean & $3.66^{\mathrm{B}}$ & $3.73^{\mathrm{A}}$ & $4.20^{\mathrm{A}}$ & & $3.69^{\mathrm{B}}$ & $3.75^{\mathrm{A}}$ & $4.23^{\mathrm{A}}$ & \\
\hline
\end{tabular}

\section{Nutrients Contents}

Regardless of the biostimulant treatments, the results show that by increasing the nitrogen supply from 75 to
$100 \%$ of the recommended rate, the $N$ content becomes stronger and the differences between them are significant. Table (6) displays the response of 
squash to nitrogen fertilizer with the reaction of biostimulants. Regarding the effect of biostimulants, the results show that spraying squash plants with EM1 or MLE either alone or in their combinations increased the $\mathrm{N}$ content compared to untreated plants. These results can be assigned to MLE which is independent of $\mathrm{N}$ fertilization and foliar treatment can increase nitrogen accumulation in plant tissues. For the interactions between nitrogen modifiers and biostimulants, the results revealed that the single application of MLE in combination with $100 \% \mathrm{~N}$ were more efficient and gave higher nitrogen content than EM1 application, in both seasons.

The main and interaction effects of biostimulants and nitrogen fertilizer doses on leaf $\mathrm{P} \%$ are given in Table (7). Differentiation by nitrogen concentrations indicated that the application of $100 \% \mathrm{~N}$ actually increased the leaf $\mathrm{P} \%$ compared to the control treatment, in both seasons and the P\% increased significantly and gradually with the permanent application of EM1 or MLE, indicating that both factors do not act separately. It was determined that the combined applications of EM1 + MLE associated with a supply of $100 \% \mathrm{~N}$ showed a higher $P$ content. As for the $K$ content, compared to the unfertilized treatment, a trend, of a significant increase in the $\mathrm{K}$ content with increasing the rate of $\mathrm{N}$ up to $100 \%$ but it is still statistically similar to other $\mathrm{N}$ rates $(75 \%)$. Treatments with various biostimulants and their interactions with $\mathrm{N}$ modifiers had no significant effect on the $\mathrm{K} \%$ of leaves, as shown in Table (8).

Furthermore, integrated treatments significantly excessed individual treatments. Among all the constituent treatments, the integrative EM1 + MLE + $100 \% \mathrm{~N}$ treatment was the best, with $\mathrm{N} \%$ increased by $90 \%$ and $77 \%$, P\% by $24 \%$ and $23 \%$ and $K \%$ by $26 \%$ and $33 \%$ in the
2019 and 2020 growing seasons, respectively. The enhancement in nutrient contents $(N, P, K)$ by application of both EM1 and MLE can be attributed to the fact that these extracts are rich sources of mineral nutrients and hormones such as GAs, auxin and zeatintype cytokinin's that increase metabolic processes including nutrient absorption that increases the content of nutrients in plant tissues (Latif and Mohamed 2016 and Hamail et al., 2014).

\section{Yield and Yield Components}

Data of the effect of treatments used on yield and its components are presented in Tables (9 and 10). Yield and its components of squash varied widely under different levels of nitrogen or application of biostimulants. The results show that $\mathbf{N}$ fertilizer levels significantly $(P<0.05)$ affected the number of quash fruits per plant and the total yield/plot. Regarding the effect of nitrogen fertilization rates on yield and its components, the results indicate a significant increase with increasing nitrogen supply up to $100 \%$ of the recommended rate, in the two seasons compared to the control treatment. Plants that obtained $100 \% \quad \mathrm{~N}$ of the recommended rate resulted in higher fruit yield and quality. However, there was a significant decrease in yield and its components when a minimum rate $\mathbf{N}$ was applied compared with the other reactions. The increase in fruit yield with the application of nitrogen levels may be due to the effect of nitrogen on enhancement of vegetative growth and leaf area/plant creating a large surface available for photosynthesis. Nitrogen is an essential nutrient in the composition of plant dry matter and many energy-rich compounds that regulate photosynthesis and plant production; thus, our results are in a complete agreement with the research previously cited by $\mathrm{Ng}$ 'etich et al. (2013) and Shafeek et al. (2016). 
Table (9): Effect of biostimulants, nitrogen rates and their interactions on the number of fruits/plant.

\begin{tabular}{|c|c|c|c|c|c|c|c|c|}
\hline Treatments & \multicolumn{7}{|c|}{$2019 / 2020$} & Seasons \\
& \multicolumn{7}{|c|}{ N levels } \\
\hline & $0 \%$ & $75 \%$ & $100 \%$ & Mean & $0 \%$ & $75 \%$ & $100 \%$ & Mean \\
\hline Control & $4.12^{\mathrm{d}}$ & $6.14^{\mathrm{C}}$ & $8.01^{\mathrm{d}}$ & $6.09^{\mathrm{D}}$ & $4.19^{\mathrm{C}}$ & $6.17^{\mathrm{C}}$ & $8.14^{\mathrm{C}}$ & $6.17^{\mathrm{D}}$ \\
\hline EM1 & $4.35^{\mathrm{C}}$ & $6.64^{\mathrm{b}}$ & $8.38^{\mathrm{bc}}$ & $6.46^{\mathrm{C}}$ & $4.47^{\mathrm{b}}$ & $6.79^{\mathrm{b}}$ & $8.47^{\mathrm{b}}$ & $6.58^{\mathrm{C}}$ \\
\hline MLE & $5.13^{\mathrm{b}}$ & $7.68^{\mathrm{ab}}$ & $8.48^{\mathrm{b}}$ & $7.10^{\mathrm{B}}$ & $5.27^{\mathrm{ab}}$ & $7.78^{\mathrm{ab}}$ & $8.68^{\mathrm{ab}}$ & $7.24^{\mathrm{B}}$ \\
\hline EM1 + MLE & $5.29^{\mathrm{a}}$ & $7.89^{\mathrm{a}}$ & $9.04^{\mathrm{a}}$ & $7.41^{\mathrm{A}}$ & $5.37^{\mathrm{a}}$ & $7.97^{\mathrm{a}}$ & $9.18^{\mathrm{a}}$ & $7.51^{\mathrm{A}}$ \\
\hline Mean & $4.72^{\mathrm{C}}$ & $7.09^{\mathrm{B}}$ & $8.48^{\mathrm{A}}$ & & $4.83^{\mathrm{C}}$ & $7.18^{\mathrm{B}}$ & $8.62^{\mathrm{A}}$ & \\
\hline
\end{tabular}

Table (10): Effect of biostimulants, nitrogen rates and their interactions on the Total yield $\mathrm{kg} / \mathrm{plot}$.

\begin{tabular}{|c|c|c|c|c|c|c|c|c|}
\hline Treatments & \multicolumn{7}{|c|}{$2019 / 2020$} & Seasons \\
& \multicolumn{7}{|c|}{ N levels } \\
\hline & $0 \%$ & $75 \%$ & $100 \%$ & Mean & $0 \%$ & $75 \%$ & $100 \%$ & Mean \\
\hline Control & $18.11^{\mathrm{d}}$ & $20.54^{\mathrm{d}}$ & $20.55^{\mathrm{d}}$ & $19.73^{\mathrm{D}}$ & $20.97^{\mathrm{d}}$ & $21.45^{\mathrm{d}}$ & $22.35^{\mathrm{d}}$ & $21.59^{\mathrm{D}}$ \\
\hline EM1 & $23.48^{\mathrm{C}}$ & $24.99^{\mathrm{bc}}$ & $32.67^{\mathrm{C}}$ & $27.05^{\mathrm{C}}$ & $24.16^{\mathrm{C}}$ & $26.93^{\mathrm{bc}}$ & $33.73^{\mathrm{C}}$ & $28.27^{\mathrm{C}}$ \\
\hline MLE & $25.48^{\mathrm{b}}$ & $26.71^{\mathrm{b}}$ & $34.08^{\mathrm{b}}$ & $28.76^{\mathrm{B}}$ & $25.81^{\mathrm{b}}$ & $27.16^{\mathrm{b}}$ & $35.11^{\mathrm{b}}$ & $29.36^{\mathrm{B}}$ \\
\hline EM1 + MLE & $25.54^{\mathrm{a}}$ & $28.98^{\mathrm{a}}$ & $35.54^{\mathrm{a}}$ & $30.02^{\mathrm{A}}$ & $27.01^{\mathrm{a}}$ & $31.26^{\mathrm{a}}$ & $37.96^{\mathrm{a}}$ & $32.08^{\mathrm{A}}$ \\
\hline Mean & $23.15^{\mathrm{C}}$ & $25.31^{\mathrm{B}}$ & $30.71^{\mathrm{A}}$ & & $24.49^{\mathrm{C}}$ & $26.70^{\mathrm{B}}$ & $32.29^{\mathrm{A}}$ & \\
\hline
\end{tabular}

Regarding to the biostimulants treatments, squash yield was positively affected by using all. However, the throughout adjustment was the same: EM1+ MLE > MLE> EM1 > control. The significant increase in the total yield over the control resulting from these treatments was $52.2,48.6$ and $54.8,36.0$ and $37.1,31.0 \%$ during the two seasons, respectively. Improving the yield and its components by spraying EM1 (Effective microorganisms) can be proposed for its beneficial role of improving flower formation especially female flowers. Moreover, this effect can be attributed to the presence of five subfamilies of microorganisms: a) Lactic acid bacteria: these bacteria are distinguishing by their strong sterilizing properties. They suppress harmful microorganisms and promote rapid decomposition of organic substances. In addition, they can eliminate the reproduction of the fungus fusarium, which is a harmful. b) Yeasts: make antimicrobial substances that are beneficial for plant growth. Their metabolites are food for other bacteria such as the lactic acid and actinomycete. c) Actinomycetes: these suppress harmful fungi and bacteria and can live simultaneously with photosynthetic bacteria. d) Photosynthetic bacteria: these bacteria play the fundamental role in the activity of EM. They synthesize beneficial substances from secretions of roots, organic matter and/or harmful gases (e.g., hydrogen sulphide) by using sunlight and the heat of soil as sources of energy. They participate to a better use of sunlight or, in other words, better photosynthesis. The metabolites sophisticated by these micro-organisms are directly absorbed into plants. Along with, these bacteria excess the number of other bacteria and act as nitrogen binders. e) Fungi: that bring about leavening these breaks down the organic substances quickly. This suppresses 
smell and prevents damage that can caused by harmful insects $(X u, 2000)$ on sweet corn. This is in agreement with similar observations by Tong (1998) on watermelons, Hafiz and Mahmoud (2003) on squash and Habashi et al. (2007) on cucumber.

Additionally, this significant result probably attributed to moringa extract concentration of $3 \%$ which caused rising in squash growth parameters, i.e., chlorophyll content and number of leaves/plant which maximized photosynthesis and increasing sink capacity through supply the photoassimilates from leaves and translocation to build high quality fruit and yield as substantive by Thomas and Howarth (2000), they illustrated that application of MLE extract whereas it is rich with zeatin like cytokinin and this may be induced cytokinin bio-synthesis in turned maximum number of photosynthetic active leaves and that is obvious from number and area of leaves per plant maintaining the chlorophylls in higher concentrations which be inverted on plant yield. Moringa leaves also, contain appropriate amounts from stimulant substances encouraged celldivision rate, cell-enlargement, strengthens plants, eventually produces more and higher yield (Fuglie, 2000). Also, Azooz et al. (2004) informed that moringa extract was capable to enhance the photosynthetic apparatus in treated plant, which leads to increase in plant productivity and fruit dry matter. Moringa leaf extract as well, contains plant growth hormone, called zeatin which has been reported to increase yields by 25 to $30 \%$ for nearly any crop as aforesaid by (Jason, 2013). Our results are a line with those found by Palada (1996) who pointed out that yield of tomato was significantly increased when treated by foliar application with moringa leaf extract. Caceres (1999) deduced that moringa leaf extract contains high level of elements and hormone which make it act as growth and yield enhancer. As well as, Culver et al. (2012) revealed that moringa extract applied every two weeks up to harvest significant increases in tomato yield and its components as well as fruit dry matter. Ozobia (2014) noted that moringa extract as foliar application was improved eggplant yield and physical characters of fruit. The same results were affirmed by many researchers as Muhammed et al. (2013) on onion and Bashir et al. (2014) on tomato, Oluwagbenga and Odeghe (2015) and Aluko (2016) on pepper.

\section{Fruit quality}

Concerning to the effect of the three levels of $\mathbf{N}$ fertilization and foliar application of bio-stimulants besides the interactions effect on fruits quality of squash plants, expressed as fruit diameter, TSS and dry matter \%. Data in Tables (11, 12 and 13) show that all combinations treatments led to significant increases in fruit quality contrast to the control treatment (Water foliar application) and at the same time enhanced its components, i.e., fruit diameter, dry matter \% as well as total soluble solids. Data also cleared that spraying squash plant with moringa leaf extract + effective microorganisms incorporated with $100 \%$ recommended nitrogen rate was sufficient to produce the superiority results of the previous parameters in the two growing seasons. The prominence effect with the combinations of EM1+ MLE than the single factor may be allocated to the integrated of each other and such this integration could be suggested to increase the effect of the individual application upon growth characters. Therefore, these results may be also attributed to the stimulatory effect upon photosynthetic pigments and minerals content. 
Table (11): Effect of biostimulants, nitrogen rates and their interactions on the diameter of fruit.

\begin{tabular}{|c|c|c|c|c|c|c|c|c|}
\hline \multirow[t]{4}{*}{ Treatments } & \multicolumn{8}{|c|}{ Season } \\
\hline & \multirow{2}{*}{\multicolumn{3}{|c|}{$2019 / 2020$}} & & \multicolumn{4}{|c|}{$2020 / 2021$} \\
\hline & & & & \multicolumn{5}{|c|}{$\mathrm{N}$ levels } \\
\hline & $0 \%$ & $75 \%$ & $100 \%$ & Mean & $0 \%$ & $75 \%$ & $100 \%$ & Mean \\
\hline Control & $11.07^{\mathrm{d}}$ & $11.53^{\mathrm{c}}$ & $13.07^{\mathrm{d}}$ & $11.89^{\mathrm{V}}$ & $11.33^{\mathrm{d}}$ & $12.40^{\mathrm{a}}$ & $13.55^{\mathrm{d}}$ & $12.43^{\mathrm{D}}$ \\
\hline EM1 & $11.60^{\mathrm{bc}}$ & $12.72^{b}$ & $13.14^{\mathrm{C}}$ & $12.49^{\mathrm{C}}$ & $11.69^{c}$ & $13.30^{\mathrm{bc}}$ & $14.50^{c}$ & $13.16^{\mathrm{C}}$ \\
\hline MLE & $12.83^{b}$ & $13.09^{\mathrm{ab}}$ & $13.50^{6}$ & $13.14^{B}$ & $12.92^{b}$ & $14.29^{b}$ & $16.74^{b}$ & $14.65^{\mathrm{B}}$ \\
\hline EM1 + MLE & $13.56^{\mathrm{a}}$ & $13.59^{\mathrm{a}}$ & $14.96^{\mathrm{a}}$ & $14.04^{A}$ & $13.77^{\mathrm{a}}$ & $15.35^{\mathrm{a}}$ & $17.32^{\mathrm{a}}$ & $15.48^{A}$ \\
\hline Mean & $12.27^{\mathrm{C}}$ & $12.73^{B}$ & $13.67^{A}$ & & $12.43^{\mathrm{C}}$ & $13.84^{\mathrm{B}}$ & $15.53^{A}$ & \\
\hline
\end{tabular}

Table (12): Effect of biostimulants, nitrogen rates and their interactions on TSS\%.

\begin{tabular}{|c|c|c|c|c|c|c|c|c|}
\hline Treatments & \multicolumn{7}{|c|}{$2019 / 2020$} & Season \\
& \multicolumn{7}{|c|}{ N levels } \\
& $0 \%$ & $75 \%$ & $100 \%$ & Mean & $0 \%$ & $75 \%$ & $100 \%$ & Mean \\
\hline Control & $3.05^{\mathrm{b}}$ & $3.65^{\mathrm{b}}$ & $3.75^{\mathrm{b}}$ & $3.48^{\mathrm{B}}$ & $3.66^{\mathrm{b}}$ & $3.85^{\mathrm{b}}$ & $4.25^{\mathrm{b}}$ & $3.92^{\mathrm{B}}$ \\
\hline EM1 & $3.65^{\mathrm{a}}$ & $4.05^{\mathrm{a}}$ & $4.15^{\mathrm{a}}$ & $3.95^{\mathrm{A}}$ & $3.87^{\mathrm{a}}$ & $4.14^{\mathrm{a}}$ & $4.20^{\mathrm{a}}$ & $4.07^{\mathrm{A}}$ \\
\hline MLE & $3.75^{\mathrm{a}}$ & $4.15^{\mathrm{a}}$ & $4.17^{\mathrm{a}}$ & $4.02^{\mathrm{A}}$ & $4.00^{\mathrm{a}}$ & $4.25^{\mathrm{a}}$ & $4.29^{\mathrm{a}}$ & $4.18^{\mathrm{A}}$ \\
\hline EM1 + MLE & $3.85^{\mathrm{a}}$ & $4.25^{\mathrm{a}}$ & $4.29^{\mathrm{a}}$ & $4.13^{\mathrm{A}}$ & $4.03^{\mathrm{a}}$ & $4.30^{\mathrm{a}}$ & $4.34^{\mathrm{a}}$ & $4.22^{\mathrm{A}}$ \\
\hline Mean & $3.58^{\mathrm{B}}$ & $4.03^{\mathrm{A}}$ & $4.09^{\mathrm{A}}$ & & $3.89^{\mathrm{C}}$ & $4.14^{\mathrm{B}}$ & $4.27^{\mathrm{A}}$ & \\
\hline
\end{tabular}

Table (13): Effect of biostimulants, nitrogen rates and their interactions on the dry matter\%

\begin{tabular}{|c|c|c|c|c|c|c|c|c|}
\hline Treatments & \multicolumn{7}{|c|}{$2019 / 2020$} & Season \\
& \multicolumn{7}{|c|}{ N levels } \\
& $0 \%$ & $75 \%$ & $100 \%$ & Mean & $0 \%$ & $75 \%$ & $100 \%$ & Mean \\
\hline Control & $4.36^{\mathrm{C}}$ & $4.48^{\mathrm{d}}$ & $4.57^{\mathrm{C}}$ & $4.47^{\mathrm{C}}$ & $4.55^{\mathrm{C}}$ & $4.87^{\mathrm{d}}$ & $5.04^{\mathrm{C}}$ & $4.82^{\mathrm{C}}$ \\
\hline EM1 & $4.40^{\mathrm{D}}$ & $4.61^{\mathrm{DC}}$ & $4.83^{\mathrm{D}}$ & $4.61^{\mathrm{B}}$ & $4.59^{\mathrm{D}}$ & $4.83^{\mathrm{C}}$ & $5.15^{\mathrm{b}}$ & $4.86^{\mathrm{B}}$ \\
\hline MLE & $4.63^{\mathrm{a}}$ & $4.70^{\mathrm{b}}$ & $5.24^{\mathrm{a}}$ & $4.86^{\mathrm{B}}$ & $4.82^{\mathrm{a}}$ & $4.89^{\mathrm{b}}$ & $5.26^{\mathrm{a}}$ & $4.99^{\mathrm{B}}$ \\
\hline EM1 + MLE & $4.93^{\mathrm{a}}$ & $5.23^{\mathrm{a}}$ & $5.28^{\mathrm{a}}$ & $5.15^{\mathrm{A}}$ & $4.99^{\mathrm{a}}$ & $5.16^{\mathrm{a}}$ & $5.31^{\mathrm{a}}$ & $5.15^{\mathrm{A}}$ \\
\hline Mean & $4.58^{\mathrm{C}}$ & $4.76^{\mathrm{B}}$ & $4.98^{\mathrm{A}}$ & & $4.74^{\mathrm{C}}$ & $4.94^{\mathrm{B}}$ & $5.19^{\mathrm{A}}$ & \\
\hline
\end{tabular}

\section{CONCLUSION}

In all cases, based on the study, it can be concluded that nitrogen fertilizer at the recommended rate $(100 \%)$ gave the preferred fruit yield and its components. The combinations of effective microorganisms plus treatment with moringa leaf extract had the best effect on the overall yield and quality. While, the single application of moringa leaf extract gave the highest number of fruits per plant.

\section{REFERENCES}

Abdalla, M.M. (2013). The potential of Moringa oleifera extract as a bio stimulant in enhancing the growth: Biochemical and hormonal contents in rocket (Eruca vesicaria subsp. sativa) plants. International Journal of Plant Physiology and Biochemistry, 5: 4249.

Aluko, M. (2016). Moringa leaf extract on the growth and yield of pepper (Capsicum annuum L.). ARPN Journal of Agricultural and Biological Science, 11(3): 107-109.

AOAC (1990). $15^{\text {th }}$ Official methods of Analysis. Association Official Analysis Chemists, Washington D.C. USA. pp: 807-928. 
Ashraf, R., B. Sultana, M. Iqbal and M. Mushtaq (2016). Variation in biochemical and antioxidant attributes of Raphanus sativus in response to foliar application of plant leaf extracts as plant growth regulator. Journal of Genetic Engineering and Biotechnology, 14: 1-8

Aslam, M., B. Sultana, F. Anwar and H. Munir (2016). Foliar spray of selected plant growth regulators affected the biochemical and antioxidant attributes of spinach in a field experiment. Turkish Journal of Agriculture and Forestry, 40: 136-145.

Azooz, M.M., M.A. Shaddad and A.A. Abdel-Latef (2004). The accumulation and compartment-ation of proline in relation to salt tolerance of three sorghum cultivars. Ind. J. Plant Physiol, 9: 1-8.

Azra, Y., S.M.A. Basra, M. Farooq, H. Rehman, N. Hussain and H.R. Athar (2013). Exogenous application of moringa leaf extract modulates the antioxidant enzyme system to improve wheat performance under saline conditions. Plant Growth Regulation, 69:225-233.

Bashir, K.A., J.A. Bawa and I. Mohammed (2014). Efficacy of leaf extract of drumstick tree (Moringa oleifera L.) on the growth of local tomato (Lycopersicon esculentum) Journal of Pharmacy and Biological Sciences, 9 (4): 74-79.

Basra, S.M.A., M.N., Iftikhar and I. Afzal (2011). Potential of moringa (Moringa oleifera) leaf extract as priming agent for hybrid maize seeds. Int. J. Agric. Biol. Eng. 13:1006-1010.

Bulgari, R., G. Cocetta, A. Trivellini, P. Vernieri and A. Ferrante (2015). Biostimulants and crop responses: $A$ review. Biological Agriculture and Horticulture, 31: 1-17.

Busani, M., J.M. Patrick, H. Arnold and M. Voster (2011). Nutritional characterization of moringa (Moringa oleifera Lam) leaves. Afr J Biotechnol, 10: 12925-12933.

Caceres, A. (1999). Phamacological properties of Moringa oleifera fiterapia. LXII (5): 44-49.

Calvo, P., L. Nelson and J.W. Kloepper (2014). Agricultural uses of plant biostimulants. Plant Soil, 383: 3-41.

Cechin, I. and T. Fumis (2004). Effect of nitrogen supply on growth and photosynthesis of sunflower plants grown in the greenhouse. Plant Sci., 166:1379-1358

Colla, G. and F. Saccardo (2003). Application of systematic variation method for optimizing mineral nutrition of soilless-grown zucchini squash. J Plant Nutr., 9:1859-1872.

Cottenie, A., M. Verloo, L. Kiekers, G. Velghe and R. Camrbynek (1982). Chemical analysis of plants and soils. State Univ. Hand Book. State Univ., Ghent, pp 1-63

Culver, M., T. Fanuel and A.Z. Chiteka (2012). Effect of moringa extract on growth and yield of tomato. Greener Journal of Agricultural Sciences, 2(5): 207-211.

El Sohaimy, S.A., G.M. Hamad, S.E. Mohamed, M.H. Amar and R.R. AlHindi (2015). Biochemical and functional properties of Moringa oleifera leaves and their potential as a functional food. Global Adv. Res. J. Agri.0c Sci., 4:188-199.

El zaawely, A.A., M.E. Ahmed, H.F. Maswada, T.D. Xuan (2016). Enhancing growth, yield, biochemical, and hormonal contents of snap bean (Phaseolus vulgaris L.) sprayed with moringa leaf extract. Archives of Agronomy and Soil Science, 1-13.

Fuglie, L.J. (2000). The Miracle Tree: Moringa oleifera: Natural nutrition for the tropics. The miracle tree: the multiple attributes of moringa. Food and Agriculture Organization, pp: 172. 
Gopalakrishnan, L., K. Doriya and D.S. Kumar (2016). Moringa oleifera: A review on nutritive importance and its medicinal application. Food Science and Human Wellness, 5: 49-56.

Habashi, N. H., M.M. Ghallab, M.A. Rizk and E.S. Mansour (2007). New approaches for controlling sucking pests on cucumber plants and their impact on the crop yield. Egyptian $\mathrm{J}$. of Biological Pest Control, 17(1/2): 131-137.

Hafiz, M.M. and A.R. Mahmoud (2003). Response of squash (Cucurbita pepo L.) to nitrogen source, nitrogen level and biofertilizer application. Annals of Agric. Sci. Moshtohor, 41(1): 283-298.

Hamail, A.F., M.S. Hamada, E.A. Tartoura and M.A. Abd El-Hady (2014). Effect of $\mathrm{N}$-forms and bio-stimulants on productivity of cucumber: 2-Flowering characters, yield and its components. J. Plant Prod. Mansoura Univ., 5(4): 573-583.

Howladar, S.M. (2014). A novel Moringa oleifera leaf extract can mitigate the stress effects of salinity and cadmium in bean (Phaseolus vulgaris L.) plants. Ecotoxicology and Environmental Safety, 100: 69-75.

Jason, P. (2013). Pepe's Fruit Trees, www.pepesplants.com

Jasso-Chaverria, C., G.J. Hochmuth, R.C. Hochmuth and S.A. Sargent (2005). Fruit yield, size and color responses of two greenhouse cucumber types to nitrogen fertilization in perlite soilless culture. Hortic. Technol., 15:422-424

Kant, S., Y.M. Bi and S.J. Rothstein (2011) Understanding plant response to nitrogen limitation for the improvement of crop nitrogen use efficiency. J Exp Bot., 62: 1499-1509.

Latif, H.H. and H.I. Mohamed (2016). Exogenous applications of moringa leaf extract effect on retrotransposon, ultrastructural and biochemical contents of common bean plants under environmental stresses. South African Journal of Botany, 106: 221231.

Lawlor, D.W. (2002). Carbon and nitrogen assimilation in relation to yield: mechanisms are the key to understanding production systems. J Exp Bot., 53:773-787.

Muhammed, R., M.M. Olorukooba, J.A. Akinyaju and E.A. Kambai (2013). Evaluation of different concentrations and frequency of foliar application of moringa extract on growth and yield of onion, (Allium cepa L.). Agrosearch, 13(3): 196-205.

Nasir, M., A. S. Khan, S.M.A. Basra and A.U. Malik (2016). Foliar applications of moringa leaf extract, potassium and zinc influence yield and fruit quality of 'Kinnow' mandarin. Scientia Horticulturae, 210: 227-235.

Ndubuaku, U.M., T.C.N. Ndubuaku, E. Ike, P.L. Ezeaku (2015). Effects of Moringa oleifera leaf extract on morphological and physiological growth of cassava and its efficacy in controlling Zonocerus variegatus. African Journal of Biotechnology, 14: 2494-2500.

Ng'etich, O.K., A.N. Niyokuri, J.J. Rono, A. Fashaho and D.J. Ogweno (2013). Effect of different rates of nitrogen fertilizer on the growth and yield of zucchini (Cucurbita pepo cv. Diamant L.) Intl. J Agric Crop Sci., 5(1): 54-62 https://www.academia.edu/4072739/IJ ACS

Oluwagbenga, D. and O.T. Odeghe (2015). Response of sweet bell pepper to moringa leaf extract and oregano biodegradable fertilizer. Asian $\mathbf{J}$ Agri. Biol., 3(4): 117-123.

Ozobia, A.P. (2014). Comparative assessment of effect of moringa extracts, NPK fertilizer and poultry manure on soil properties and growth performance of Solanium menlongina 
in Abuja, North Central Region of Nigeria. Journal of Agricultural and Crop Research, 2(5): 88-93

Palada, M.C. (1996). Moringa versatile tree crop with horticultural potential in the sub-tropical. United State. Hort. Sci., 31(5): 794-797.

Phiri, C. and D.N. Mbewe (2010). Influence of Moringa oleifera leaf extracts on germination and seedling survival of three common legumes. International Journal of Agriculture and Biology, 12: 315-317.

Pokluda, R., Sami M. Shehata and T. Kopta (2018). Vegetative, Chemical Status and Productivity of Zucchini Squash (Cucurbita pepo L.) Plants in Responses to Foliar Application of Pentakeep and Strigolactones Under NPK Rates. Gesunde Pflanzen, 70:2129.

Rady, M.M. and G.F. Mohamed (2015). Modulation of salt stress effects on the growth, physio-chemical attributes and yields of Phaseolus vulgaris L. plants by the combined application of salicylic acid and Moringa oleifera leaf extract. Sci Horti., 193: 105-113.

Rady, M.M., B.C. Varma and S.M. Howladar (2013). Common bean (Phaseolus vulgaris L.) seedlings overcome $\mathrm{NaCl}$ stress as a result of presoaking in Moringa oleifera leaf extract. Scientia Horticulturae, 162: 63-70.

Rehman, H., H. Iqbal, S. Basra, I. Afzal, M. Farooq, A. Wakeel and W. Ning (2015). Seed priming improves early seedling vigor, growth and productivity of spring maize. Journal of Integrative Agriculture, 14: 1745-1754.

Shafeek, M.R., Y.I. Helmy and A.A. Ahmed (2016). Productivity of Squash plant to Mineral and Bio-Nitrogen Fertilizers on plant Growth, Total fruit Yield and leaves mineral content on a Sandy Soil. International Journal of Chem. Tech. Research., 9(3): 66-75.
Sumeet, G., U. Shahid, S. Suryapani (2009). Nitrate accumulation, growth and leaf quality of spinach beet (Beta vulgaris Linn.) as affected by NPK fertilization with special reference to potassium. Indian J Sci Technol., 2(2): 35-40

Swelam, W.M. (2012). Effect of organic fertilizer, biofertilizer and some foliar application treatments on the yield and quality of sweet pepper. M.Sc. Thesis, Fac. of Agric., Mans. Univ., Egypt.

Thomas, H. and C.J. Howarth (2000). "Five ways to stay green," Journal of Experimental Botany, 51: 329-337.

Tilly-Mándy, A., P. Honfi, E. StefanovitsBányai, I.D. Mosonyi, V. Köbli and K. Hrotkó (2010). The effect of 5aminolevulinic-acid (ALA) on the development of Saintpaulia ionantha. Int J Hortic Sci., 16(5): 33-36.

Tong, L.Y. (1998). Experiments on the practical effects of a new EM on several crops. Zhejiang Nongye Kexue, 2: 65-66.

Wilde, S.A., R.B. Corey, J.C. Lyer and G.K. Voigt (1985) "Soil and Plant Analysis for Tree Culture", $3^{\text {rd }}$. Oxford and IBM Publishers. New Delhi. India. pp. 93-106.

Wu, F., L. Wu and F. Xu (1998). Chlorophyll meter to predict nitrogen side dress requirement for shortseason cotton (Gossypium hirsutum L.). Field Crops Res., 56: 309-314

$\mathrm{Xu}, \mathrm{H}$. (2000). Effects of a microbial inoculant and organic fertilizers on the growth, photosynthesis and yield of sweet corn. J. Crop Prod., 3: 183-214.

Yaronskaya, E., I. Vershilovskaya, Y. Poers, A.E. Alawady, N. Averina and B. Grimm (2006). Cytokinin effects on tetrapyrrole biosynthesis and photosynthetic activity in barley seedlings. Planta, 224(3): 700-709. 


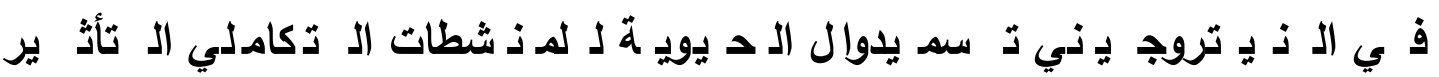

$$
\begin{aligned}
& \text { ذ موال ت د سد ين } \\
& \text { ال كو سة ق رع وإذ تاج ية } \\
& \text { محمد عبد المحسن محمد طه } \\
& \text { قسم البساتين - كلية الزراعة - جامعة المنوفية }
\end{aligned}
$$

الملخص العربى

تهاف الدراسة الحالية إلى إظهار الإختلافات فى النمو الخضري والمحتوي الكيماوي والإنتاجية لمحصول قرع الكوسة

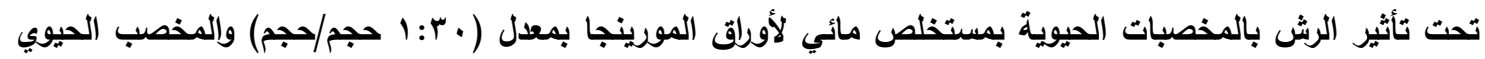

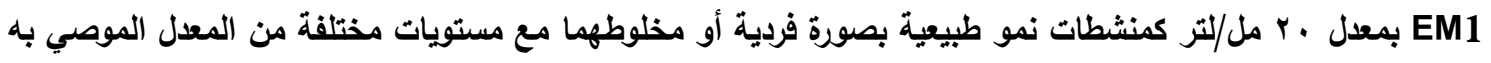

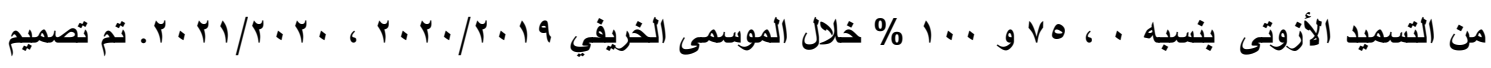

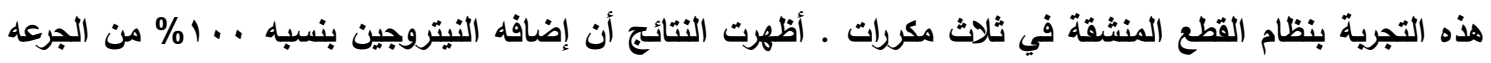

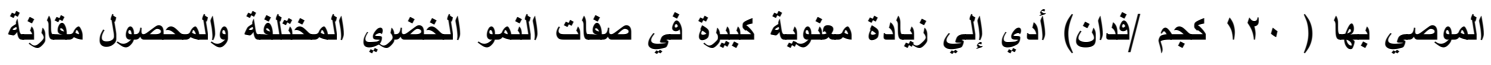

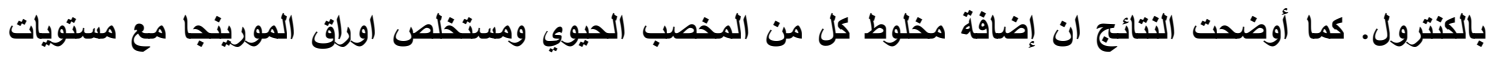
التسميد الأزوتى أدت الي زيادة معنوية في المحصول والتركيب الكيماوى للثمار مقارنة بمعاملة الكنترول. 
أ.د/ عبدالفتاح حسن سليم قسم النبات الزراعى - كلية الزراعة - جامعة المنوفية أ.د/ فتوح أبو اليزيد على فسم البساتين - كلية الزراعة - جامعة المنوفية 